\title{
Pengembangan Sumber Daya Manusia Jabatan Fungsional Analis Kepegawaian di Badan Penelitian dan Pengembangan Kesehatan
}

\author{
Nunuk Arie Suryana ${ }^{1}$ \\ nunukariesuryana@yahoo.com \\ Zulfa Auliyati Agustina ${ }^{2}$ \\ zoelauliya@gmail.com \\ ${ }^{1}$ PengembanganSumber Daya Manusia Universitas Airlangga \\ ${ }^{2}$ Puslitbang Humaniora dan Manajemen Kesehatan, Kementrian Kesehatan RI.
}

\begin{abstract}
ABSTRAK
Perencanaan sumber daya manusia dilakukan untuk mengantisipasi permintaan atau kebutuhan tenaga kerja organisasi di masa yang akan datang, sehingga kinerja seseorang dalam organisasi merupakan salah satu faktor yang turut menentukan langkah keberhasilan suatu organisasi. Sumber daya manusia yang kurang mendapat perhatian akan menimbulkan keresahan, turunnya semangat dan kegairahan kerja, merosotnya loyalitas dan prestasi yang bersangkutan. Dengan munurunnya semangat dan kegairahan kerja, maka akan mengakibatkan tingginya tingkat kemangkiran pegawai yang dapat merugikan organisasi. Jabatan fungsional analis kepegawaian merupakan ujung tombak manajemen PNS sehingga harus memahami manajemen kepegawaian mulai dari rekruitmen, penempatan maupun promosi hingga pemberhentian, selain itu mengharapkan kepada peserta Diklat untuk menjadi agents of change terhadap citra negatif PNS dan juga harus menjalankan fungsi sosialisasi regulasi kepegawaian di lingkungan kerjanya. Pendekatan dalam penelitian ini adalah kualitatif. Pendekatan kualitatif digunakan karena tujuan utama dari penelitian ini berusaha untuk memberikan gambaran dalam pelaksanaan Pengembangan Sumber Daya Manusia Jabatan Fungsional Analis Kepegawaian di Badan Litbang Kesehatan. Dalam penelitian ini menggunakan tiga komponen yang mempengaruhi keberhasilan pengembangan sumber daya manusia jabatan fungsional analis kepegawaian yaitu pengembangan individu, pengembangan karir, manajemen kinerja.
\end{abstract}

Kata Kunci: Pengembangan sumber daya manusia, pengembangan individu, pengembangan karir

\begin{abstract}
Human resource planning is done to anticipate the demands or needs of the organization's workforce in the future, so that a person's performance in the organization is one of the factors that determine the success of an organization. Human resources that lack attention will lead to unrest, a decrease in enthusiasm and enthusiasm for work, a decline in loyalty and achievement in question. With the decline in enthusiasm and enthusiasm for work, it will result in a high level of absenteeism that can harm the organization. The functional position of the staff analyst is the spearhead of PNS management so that it must understand staffing management starting from recruitment, placement and promotion to dismissal, besides expecting Diklat participants to become agents of change towards the negative image of civil servants and also having to carry out the function of socializing regulatory staff in their work environment. The approach in this study is qualitative. A qualitative approach is used because the main purpose of this study seeks to provide an overview in the implementation of Human Resource Development in the Job Analyst Functional Position in the Health Research and Development Agency. In this study using three components that influence the success of human resource development functional positions of staff analysts, namely individual development, career development, performance management.
\end{abstract}

Keywords: Human resource development, individual development, career development. 


\section{PENDAHULUAN}

Aparatur Sipil Negara (ASN) adalah profesi bagi pegawai negeri sipil dan pegawai pemerintah dengan perjanjian kerja yang bekerja pada instansi pemerintah. ASN memiliki tanggung jawab terhadap beban tugas dan pekerjaan. Penempatan pegawai sangat berpengaruh terhadap kinerja ASN. Mathis dan Jackson (2006:262) menyatakan bahwa "penempatan adalah menempatkan posisi seseorang ke posisi pekerjaan yang tepat, seberapa baik seorang karyawan cocok dengan pekerjaanya akan mempengaruhi jumlah dan kualitas pekerjaan." Penempatan posisi kerja selain sebagai upaya memperbaiki kinerja juga biasanya dilakukan untuk menyesuaikan kebutuhan instansi atau pada bagian tertentu. Hasil informasi jabatan dapat digunakan untuk pemetaan pegawai, penempatan pegawai, sampai promosi jabatan.

Yulina Setiawati, Deputi Bidang Pembinaan Manajemen Kepegawaian, menjelaskan bahwa Tahun 2016 Indonesia sebagai Negara dengan jumlah penduduk terbesar keempat didunia, jumlah populasi mencapai 237 juta penduduk (sensus 2013). Jumlah PNS per Desember 2016 sebanyak 4.498.643 (BKN 2016), yang terbagi menjadi dua, yaitu PNS Pusat dan PNS daerah. Rasio PNS Pusat sebanyak $20,94 \%$ atau sejumlah 942.016 pegawai, sedangkan rasio PNS Daerah sebanyak $79,06 \%$ atau sejumlah 3.556 .627 pegawai.

Tahun 2016 KemenPAN-RB menerbitkan Peraturan Menteri PANRB Nomor 25 Tahun 2016 tentang Nomenklatur Jabatan Pelaksana Bagi Pegawai Negeri Sipil (PNS) di Lingkungan Instansi Pemerintah. Kepala Bidang Perencana SDM Aparatur KemenPANRB, Syamsul Rizal mengatakan bahwa mulai Januari 2017, JFU tidak berlaku lagi. Jabatan fungsional tertentu di lingkungan Kementerian Kesehatan Tahun 2017 ada 48 jenis jabatan. Jumlah pegawai yang sudah menduduki jabatan fungsional tertentu berjumlah 25.882 pegawai. Biro Kepegawaian telah membuat proyeksi kebutuhan pegawai selama 5 Tahun mulai dari Tahun 2018 sampai 2022, maka pada tahun 2018 sampai 2022 kebutuhan jabatan fungsional dilingkungan Kemenkes 67.280. Hasil tersebut dihitung dari jumlah data pegawai yang akan pensiun selama 5 Tahun kedepan dan data kebutuhan selama 5 tahun kedepan.

Badan Litbang Kesehatan memiliki tujuh jabatan fungsional lainnya yang terdiri dari peneliti, pustakawan, arsiparis, analis kepegawaian, pranata humas, pranata komputer, pengelola pengadaan barang jasa, dan perancang peraturan Per UU. Jalur karir jabatan fungsional Analis 
Kepegawaian di Badan Litbang Kesehatan telah dibuka sejak tahun 2010, yang terakhir melalui Keputusan Menteri Negara Pendayagunaan Aparatur Negara, Nomor PER/36/M.PAN/11/2006 tentang Jabatan Fungsional Analis Kepegawaian dan Angka Kreditnya sebagaimana telah diubah dengan Nomor PER/14/M.PAN/6/2008 merupakan keputusan yang dibuat dalam rangka meningkatkan mutu perencanaan, pembinaan, dan ketatausahaan kepegawaian yang memerlukan PNS yang ditugaskan secara penuh untuk melakukan kegiatan pengelolaan kepegawaian pada instansi pemerintah, khususnya Badan Litbang Kesehatan, serta menjamin pembinaan karir kepangkatan, jabatan, dan meningkatkan profesionalisme Analis Kepegawaian.

Jadi jumlah jabatan fungsional yang berada di lingkungan Badan Litbang Kesehatan adalah 537 orang. Kondisi tersebut menunjukkan bahwa jabatan fungsional merupakan wadah pengembangan karir bagi pejabat fungsional dan mendorong terciptanya organisasi yang berorientasi pada kompetensi (professional based) dan sekaligus dapat memacu profesionalisme.

Menurut Peraturan Kepala BKN No. 11 Tahun 2012 tentang Petunjuk Teknis Jabatan Fungsional Analis Kepegawaian, dijelaskan bahwa Jabatan Fungsional Analis Kepegawaian adalah Pegawai Negeri Sipil (PNS) yang diberi tugas, tanggung jawab, wewenang dan hak secara penuh oleh pejabat yang berwenang untuk melakukan kegiatan manajemen PNS dan pengembangan sistem manajemen PNS. Pembinaan jabatan fungsional Analis Kepegawaian lebih mempunyai prospek terhadap pengembangan profesi dan karir bagi seorang PNS yang memiliki bakat, keterampilan dan kecakapan atau keahlian untuk dikembangkan. Jabatan fungsional Analis Kepegawaian diberikan tunjangan jabatan yang besarnya juga diatur dalam peraturan pemerintah yang bertujuan untuk meningkatkan kesejahteraan dan produktivitas kerja Analis Kepegawaian.

Tahun 2014 Yuyun Widayanti menulis jurmal berjudul "Pengembangan Karir Pustakawan Melalui Jabatan Fungsional", ditulis bahwa pengembangan karier pustakawan melalui jabatan fungsional sangatlah tergantung pada jumlah angka kredit yang disyaratkan dalam Keputusan Menpan Nomor 132/KEP/M.PAN/12/2002 tentang jabatan fungsional pustakawan dan angka kreditnya.

Tahun 2015, Muhammad Muhajir menulis jurnal berjudul "Analisis Pengembangan Karir Pegawai pada Kantor Dinas Pendapatan Daerah Provinsi 
Sulawesi Tengah". Jenis penelitian kualitatif, dengan hasil bahwa pengembangan karir pegawai pada Kantor Dinas Pendapatan Daerah Provinsi Sulawesi Tengah dilihat dari faktor Perlakuan yang adil belum maksimal, pengembangan karir perlu perbaikan dimasa yang datang

Tahun 2016, Budi Suhariyanto menulis jurnal berjudul "Rekonstruksi Pengembangan Karier Jabatan Fungsional Panitera Pengganti Peradilan di Indonesia", hasilnya antara lain pola karier fungsional Panitera Pengganti pada lembaga peradilan di Indonesia senyatanya berbeda-beda sesuai pengaturan instansinya masing-masing dan tidak ada keterpaduannya sama sekali.

\section{LANDASAN TEORI}

\section{A. Pengembangan sumber daya manusia}

Dalam perkembangannya, sumber daya manusia merupakan hal yang vital bagi tumbuhkembangnya organisasi. Sumber daya manusia membutuhkan perhatian sehingga menimbulkan kontribusi positif bagi organisasi. Maka selanjutnya, sumber daya manusia membutuhkan kesempatan dan ruang untuk berkembang. Menurut Chris Rowley dan Keith Jackson (2012:88) pengembangan sumber daya manusia adalah sebuah proses yang dilakukan untuk mengembangkan pengetahuan, keahlian, dan kemampuan pekerja, demikian juga dengan kompetensi-kompetensi yang dikembangkan melalui pelatihan dan pengembangan, pembelajaran organisasi, manajemen kepemimpinan, dan manajemen pengetahuan untuk kepentingan peningkatan kinerja.

Tujuan pengembangan sumber daya manusia

Pengembangan sumber daya manusia memiliki tujuan dan manfaat yang sangat komplek, bagi organisasi, pegawai maupun untuk pelanggan dari organisasi (masyarakat). mengutip pendapat komang Komang, (2012) bahwa pengembangan sumber daya manusia memiliki tujuan; Produktifitas kerja, Efisiensi, Kerusakan, Kecelakaan, Pelayanan, Moral, Karier, Konseptual, Kepemimpinan, Balas jasa, Konsumen.

\section{B. Pengembangan Karir}

Selanjutnya berkaitan dengan karir, Menurut Veitzhal Rivai (2003:290) mendefinisikan pengembangan karir adalah sebagai berikut "Pengembangan karir adalah proses peningkatan kemampuan kerja individu yang dicapai dalam rangka mencapai karir yang diinginkan". Pendapat lain seperti yang dikemukakan oleh Andrew J. Dubrin yang dikutip oleh Anwar PrabuMangkunegara (2000:77) adalah sebagai berikut "Pengembangan karir adalah aktivitas 
kepegawaian yang membantu pegawaipegawai

merencanakan karir masa depan mereka di perusahaan agar perusahaan dan pegawai yang bersangkutan dapat mengembangkan diri secara maksimum."

Dalam penelitian ini menggunakan tiga komponen yang mempengaruhi keberhasilan pengembangan sumber daya manusia jabatan fungsional analis kepegawaian yaitu pengembangan individu, pengembangan karir, manajemen kinerja. Ketiga komponen tersebut dipergunakan untuk mengetahui Pengembangan Sumber Daya Manusia Jabatan Fungsonal Analis Kepegawaian pada Badan Litbang Kesehatan dapat dilaksanakan dengan efektif dan efisien.

\section{METODE PENELITIAN}

\section{A. Objek Penelitian}

Penelitian ini berawal dari asumsi adanya permasalahan pengembangan sumber daya manusia jabatan fungsional analis kepegawaian di Badan Litbang Kesehatan, yang kemudian menggunakan kerangka penafsiran berupa teori pengembangan sumber daya manusia yang memiliki tujuan untuk mengeksplorasi asumsi dalam penelitian ini.

Strategi penelitian yang digunakan adalah case study, karena dalam penelitian ini berusaha untuk menyelidiki isu pengembangan sumber daya manusia jabatan fungsional analis kepegawaian di Badan Litbang Kesehatan

B. Pendekatan

Pendekatan dalam penelitian ini adalah kualitatif. Pendekatan kualitatif digunakan karena tujuan utama dari penelitian ini berusaha untuk memberikan gambaran dan pelaksanaan Pengembangan Sumber Daya Manusia Jabatan Fungsional Analis Kepegawaian di Badan Litbang Kesehatan.

Pendekatan kualitatif menurut Noor (2009: 32) adalah suatu proses penelitian dan pemahaman yang berdasarkan pada metodologi yang menyelidiki suatu fenomena sosial dan masalah manusia, menekankan sifat realitas yang terbangun secara sosial, hubungan erat antara peneliti dengan subjek yang diteliti.

\section{Teknik Pengumpulan Data} secara komprehensif, untuk menyelidiki isu tersebut cerita-cerita dikumpulkan dari informan. Informan kemudian diwawancarai secara individu, dan melakukan observasi serta menggunakan literatur dokumen untuk mengetahui bagaimana sesungguhnya dan faktor yang mempengaruhinya. Penelitian ini merupakan penelitian deskriptif, karena berusaha menggambarkan fenomena pengembangan sumber daya manusia 
jabatan fungsional analis kepegawaian di Badan Litbang Kesehatan dengan kondisi apa adanya.

\section{HASIL DAN PEMBAHASAN}

Analisis hasil observasi, wawancara, dan studi dokumen yang merupakan gambaran dari pelaksanaan pengembangan sumber daya manusia fungsional analis kepegawaian di Badan Litbang Kesehatan. Analisis pengembangan sumber daya manusia fungsional analis kepegawaian dilakukan dengan fokus kepada individu yang meliputi pengembangan individu, pengembangan karir, dan manajemen kinerja.

\section{A. Pengembangan Individu Jabatan Analis Kepegawaian.}

Poniman dan Hidayat (2015) mengatakan bahwa pengembangan individu merupakan proses untuk meningkatkan pengetahuan, keterampilan dan perilaku secara personal melalui kegiatan belajar baik secara formal maupun informal untuk meningkatkan kapasitas individu baik untuk saat ini maupun masa depan. Berdasarkan hasil temuan lapangan diperoleh bahwa Badan Litbang Kesehatan melakukan aktivitas pengembangan individu yang dilakukan diseluruh satuan kerja Badan Litbang Kesehatan, hal ini terungkap dari hasil observasi dan wawancara dengan fungsional analis kepegawaian.
Pengembangan individu seperti tugas belajar dan ijin belajar yang diajukan oleh seluruh unit di Kementerian Kesehatan. Selain itu tahapan yang dilakukan oleh Badan Litbang Kesehatan terkait dengan pengembangan indivdu adalah analisis kebutuhan pengembangan individu yang sudah dilakukan oleh Badan Litbang Kesehatan adalah membuat analisis kebutuhan formasi jabatan analis kepegawaian melalui $\mathrm{ABK}$, menetapkan tujuan, pendekatan dalam pengembangan individu, action, serta monitoring dan evaluasi.

B. Pengembangan Karir Jabatan Fungsional Analis Kepegawaian

Sumber daya manusia menurut beberapa pakar seperti, Greenhaus (1987), Aufrey Collin (2006), Noe (2010), Bernardin dan Russel (2011), Dessler (2015) mengatakan bahwa karir merupakan rangkaian posisi atau jabatan yang ditempati seseorang dalam lingkungan suatu organisasi. Konsep definisi tersebut dapat kita katakan bahwa karir fungsional analis kepegawaian adalah rangkaian posisi atau jabatan yang ditempati seorang analis kepegawaian dalam suatu organisasi. Keputusan Menteri Negara Pendayagunaan Aparatur Negara, Nomor PER/36/M.PAN/11/2006 tentang Jabatan Fungsional Analis Kepegawaian dan Angka Kreditnya, dalam peraturan 
tersebut jelas bahwa analis kepegawaian merupakan pejabat karir yang terdiri dari jenjang jabatan analis kepegawaian tingkat terampil dan jabatan analis kepegawaian tingkat ahli.

Karir analis kepegawaian tidak boleh rangkap jabatan. Jika seorang diangkat menjadi jabatan strukturan, maka pegawai tersebut harus diberhentikan sementara dari jabatan analis kepegawaian. Karir fungsional analis kepegawaian di Badan Litbang Kesehatan bergerak sangat lambat, padahal jenjang karir fungsional analis kepegawaian sudah jelas. Maksimal seseorang analis kepegawaian untuk naik ke jenjang yang lebuh tinggi adalah 5 tahun, namun bila sampai 5 tahun belum bisa, masih diberikan satu tahun bebas sementara untuk mengumpulkan angka kredit. Selain itu Badan Litbang Kesehatan juga memiliki roadmap pengembangan sumber daya manusia yang isinya selain mengenai studi lanjut juga berisi tentang target jenjang karir fungsional analis kepegawaian hingga tahun 2018. Hal ini seperti yang diungkapkan oleh informan berikut. Fungsional analis kepegawaian juga mengetahui adanya roadmap pengembangan karir fungsional analis kepegawaian, namun ternyata analis kepegawaian belum mengetahui jika di dalam roadmap berisi tentang pengembangan karir, yang mereka tahu roadmap hanya berisi tentang kebutuhan untuk sekolah lanjut.

\section{Manajemen Karir Fungsional Analis Kepegawaian}

Manajemen Karir menurut Gilley et al (2002 : 60) adalah sebagai sebuah proses yang berkelanjutan mempersiapkan, mengimplementasikan dan memantau rencana karir yang dilakukan oleh individu sendiri dalam sistem karier organisasi. Dari definisi diatas terlihat jelas bahwa organisasi memiliki tugas membantu karyawannya dalam mengelola karirnya. Dari hasil wawancara, kegiatan manajemen kinerja yang dilakukan oleh Badan Litbang Kesehatan meliputi : proses kenaikan pangkat, proses kenaikan jenjang jabatan fungsional analis kepegawaian, pembuatan roadmap pengembangan sumber daya manusia, pembinaan karir fungsional analis kepegawaian, dan pembuatan peta jabatan, fasilitasi tugas belajar dan ijin belajar, serta fasilitasi diklat, workshop, dan forum ilmiah.

Adanya restrukturisasi Badan Litbang kesehatan, fungsi manajeman karir menjadi tanggung jawab Subbagian Kepegawaian, hal ini berbeda sebelumnya dimana fungsi manajemen karir menjadi tanggung jawab Subbagian Pengembangan Pegawai. Keadaan restrukturisasi mengakibatkan pekerjaan yang berkaitan dengan kepegawaian hanya dikerjakan 
oleh satu subbagian, berbeda dengan sebelumnya yang dikerjakan oleh subbagian pengembangan pegawai dan Subbagian Pengadaan dan Mutasi Pegawai. Keadaan ini membuat beban kerja Subbagian Kepegawaian begitu berat. Kegiatan manajemen karir fungsional peneliti yang kami lakukan antara lain, proses kenaikan jabatan dan pangkat, penyusunan roadmap pengembangan sumber daya manusia, pola karir, dan pembinaan karir fungsional analis kepegawaian di Badan Litbang Kesehatan.

\section{Menurut Peraturan Kepala BKN} Nomor 35 Tahun 2011 tentang Pedoman Penyusunan Pola Karir Pegawai Negeri Sipil, peta jabatan didefinisikan sebagai susunan nama dan tingkat jabatan struktural dan fungsional yang tergambar dalam suatu struktur unit organisasi dari tingkat yang paling rendah hingga tingkat yang paling tinggi. Definisi di atas sebenarnya sama dengan definisi jalur karir, Wayne F Cascio (2006 : 31) mengatakan bahwa jalur karir menggambarkan urutan posisi yang logis berdasarkan apa yang sebenarnya dilakukan oleh seseorang dalam organisasi. Sehingga dari definisi Wayne F Cascio, maka peta jabatan dapat dikatakan sebagai jalur karir yang ada dalam sebuah organisasi.
Permasalahan yang terjadi di Badan Litbang Kesehatan saat ini adalah peta jabatan yang membatasi gerak fungsional analis kepegawaian untuk berkarir di tingkat Balai dan Loka, seperti yang sudah disampaikan sebelumnya oleh Kepala Subbagian Kepegawaian. Badan Litbang Kesehatan setingkat Loka dan Balai jenjang jabatan fungsional analis kepegawaian hanya jenjang sampai analis kepegawaian pertama, satuan kerja Badan Litbang Kesehatan setingkat Balai Besar dan Pusat, jenjang analis kepegawaian sampai tingkat muda. Sedangkan jabatan fungsional analis kepegawaian madya di Badan Litbang Kesehatan.

C. Faktor dan Kendala Pengembangan Sumber Daya Manusia Fungsional Analis Kepegawaian

Pengembangan sumber daya manusia fungsional analis kepegawaian di Badan Litbang kesehatan, dari pembahasan di atas sudah terlihat jelas beberapa permasalahan yang bisa kita simpulkan dalam pengembangan fungsional analis kepegawaian di Badan Litbang kesehatan, diantaranya adalah :

a. Belum adanya analisis kebutuhan pendidikan dan pelatihan atau training need analysis di Badan Litbang Kesehatan. 
b. Belum adanya evaluasi dampak setelah tugas belajar setelah selesai.

c. Mentoring atau pembinaan fungsional analis kepegawaian secara terstruktur belum berjalan dengan baik.

d. Kuota tugas belajar dari Badan PPSDM Kesehatan yang terbatas..

e. Badan Litbang Kesehatan belum menemukan formulasi perhitungan kebutuhan analis kepegawaian setiap jenjang.

f. Adanya perbedaan cara pandang antara BKN dan Biro Kepegawaian Kementerian Kesehatan tentang kebijakan pengembangan karir fungsional analis kepegawaian.

\section{PENUTUP}

Memperhatikan hasil pemetaan kebijakan tentang pengembangan fungsional analis kepegawaian dan analisis pengembangan jabatan fungsional analis kepegawaian di Badan Litbang Kesehatan, maka dapat disimpulkan sebagai berikut:

1. Pengembangan sumber daya manusia jabatan fungsional analis kepegawaian di Badan Litbang Kesehatan sudah berjalan, walaupun belum dapat dikatakan efektif. Hal ini dikarenakan hasil temuan selama penelitian menunjukkan masih ada aktivitas pengembangan sumber daya manusia yang belum dilakukan, antara lain tidak ada kebutuhan beban kerja fungsional analis kepegawaian per jenjang jabatan

2. Pengembangan individu di Badan Litbang Kesehatan tidak ada analisis kebutuhan untuk diklat kompetensi analis kepegawaian, sehingga menyebabkan program diklat tidak berjalan dengan baik, masih banyak fungsional analis kepegawaian yang ikut serta dalam sebuah diklat tidak sesuai dengan kebutuhan.

3. Pembinaan atau mentoring fungsional analis kepegawaian sebenarnya merupakan unsur utama dari tugas analis kepegawaian, dan di Badan Litbang Kesehatan sejak tahun 2011 memiliki skema pembinaan terstruktur, namun tidak semua berjalan dengan baik, hal ini dikarenakan masih banyak para analis kepegawaian senior yang tidak melakukan mentoring kepada para analis kepegawaian junior.

\section{DAFTAR PUSTAKA}

Abidin, Zainal Said (2002). Kebijakan Publik. Jakarta : Yayasan Pancur Siwah. 
Agustino, Leo (2008). Dasar-Dasar

Kebijakan Publik. Bandung:

Alfabeta.

Anwar Prabu Mangkunegara (2000) Manajemen Sumber Daya Manusia Perusahaan, Cetakan Ke 2, Bandung, PT. Remaja Rosda Karya

Ardana, I Komang dkk. 2012. Manajemen Sumber Daya Manusia. Yogyakarta: Graha ilmu

Armstrong, Michael. 2006. Performance Management Key Strategies and Practical Guedelines 3rd Edition. London-Philadhelpia: Kogan Page Limited.

Brown, Judith.Training Needs Assessment: A Must for Developing an Effective Training Program Public Personnel Management 31.4 (Winter 2002): 569-574.

Budi Suhariyanto (2016), Rekonstruksi Pengembangan Karier Jabatan Fungsional Panitera Pengganti Peradilan di Indonesia, Jurnal Hukum dan Peradilan, Volume 5, Nomor 3.

Cahayani, Ati (2003). Dasar-dasar Organisasi dan Manajemen, Jakarta : PT Grasindo.

Chris Rowley \& Keith Jackson. 2012. Manajemen Sumber Daya Manusia The Key Concepts, Cetakan Kesatu, Jakarta. PT Rajagrafindo Persada.
Danang, Sunyoto. (2012). Manajemen Sumber Daya Manusia, Jakarta: PT Buku Seru. http://repository.upi.edu/17628/4/S_ MBS_1001311_Bibliography Dessler Gary. 2015. Manajemen Sumber Daya

Manusia.Edisi Ke-14.

Diterjemahkan oleh : Diana Angelica. Jakarta : Salemba Empat.

Dunn, William N (1998), Pengantar Analisis Kebijakan Publik, Edisi Kedua (terjemahan), Gadjah Mada University:Yogyakarta.

Dunn, William N. (2003). Pengantar Analisis Kebijakan Publik, Edisi Kedua. Yogyakarta : Gajah Mada University Press.

Edward III, George C. (1980). Implementing Public Policy, Washington D.C. : Congressional Quarterly Inc.

Grazulis Vladimiras dan Andrius Valickas. (2013). Development of Career System of Civil Service : The Lithuanian Case. Vilnius, Lithuania. Handoko, Hani T. (2000) "Manajemen Personalia dan Sumber Daya Manusi” ,Edisi ke-4, BFPE: Yogyakarta.

Ismana, Arya (2000). Implementasi Kebijakan Jabatan Fungsional sebagai Jalur Pengembangan Karir 
(Studi Kasus Pada Badan

Pertanahan Nasional). Tesis.

Yogyakarta: Universitas Gadjah Mada.

Marwansyah. (2012). Manajemen Sumber Daya Manusia. Alfabeta:Bandung

Mathis R.L dan Jackson J.H, 2002, Manajemen Sumber daya Manusia, Salemba Empat, Jakarta.

Muhammad Muhajir (2015), Analisis Pengembangan Karir Pegawai pada kantor Dinas Pendapatan Daerah Provinsi Sulawesi Tengah, e-Jurnal Katalogis, Volume 3 Nomor 12.

Mustopodidjaja (1992). Studi Kebijakan.

Jakarta : Lembaga Penerbit Fakultas Ekonomi Universitas Indonesia

Nawawi, Hadari. (2006). "Evaluasi dan manajemen kinerja di lingkungan perusahaan dan industry”, Gadjah Mada Univercity Press: Yogyakarta.

Noe, Raymond A, et al. 2010. Human Resources Management : Gaining a Competitive Advantage. Boston. McGraw Hill.

Pasolong, Harbani (2007). Teori Administrasi Publik. Bandung : CV Alfabeta.

Poniman Farid dan Yayan Hadiyat. (2015). Manajemen HR STIFIn Terobosan Untuk Mendongkrak Produktivitas. Jakarta : PT Gramedia Pustaka Utama
Robins, Stephen.P dan Timothy A. Judge (2008). Perilaku Organisasi,Organizations Behavior, Edisi 12, Buku 2. Jakarta : Salemba Empat.

Sedarmayanti. 2016. Manajemen Sumber Daya Manusia Reformasi Birokrasi dan Manajemen Pegawai Negeri Sipil. Bandung. PT Refika Aditama. Siagian, Sondang P. (1985). Organisasi, Kepemimpinan dan Perilaku Administrasi. Jakarta : LPEEUI. (2007). Fungsi-Fungsi Manajerial, Edisi Revisi. Jakarta : PT Bumi Aksara.

Simanjuntak, Payaman J. (1985). Pengantar Ekonomi Sumber Daya Manusia. Jakarta: Lembaga Penerbit

Fakultas Ekonomi Universitas Indonesia.

Soetrisno (1998), Bahan Diklat Prajabatan Golongan II : Dasardasar Administrasi Perkantoran. Jakarta : LAN RI.

Subarsono, A.G. (2005), Analisis Kebijakan Publik : Konsep, Teori dan Aplikasi, Yogyakarta : Pustaka Pelajar.

Sugiyono (2008), Metode Penelitian Administrasi, Dilengkapi dengan Metode R\&D, Edisi Revisi, Alfabeta, Bandung. 
Sugiyono (2008), Metode Penelitian

Administrasi, Dilengkapi dengan

Metode R\&D, Edisi Revisi, Alfabeta,

Bandung.

Susanti, Wiwin (2004). Peningkatan Karier Pejabat Fungsional Analis Kepegawaian Pada Biro Organisasi Dan Kepegawaian LIPI. Skripsi. Jakarta : STIA LAN RI.

Tanjung, Yurisna (2005), Penilaian Kritis atas Model Proses Implementasi Kebijakan Donald S. Van Meter dan C.E. Van Horn, KESKAP Jurnal Ilmu-ilmu Sosial, Vol.3 No.2/Juni 2005, Universitas Muhammadiyah Sumatera Utara.

The Liang Gie (1965). Ilmu Administrasi. Yogyakarta : Liberty.

Thoha, Miftah (2005). Birokrasi Politik di Indonesia. Jakarta : Raja Grafindo Persada.

Thoha, Miftah. 2000. Peranan Ilmu Administrasi Publik dalam Mewujudkan Tata Kepemerintahan yang baik. Yogyakarta: PPs UGM

Umar, Husein (2008). Desain Penelitian MSDM dan Perilaku Karyawan, Paradigma Positivistik dan Berbasis Pemechan Masalah.

Jakarta:Rajawali Pers.

Van Meter, Donald S. and Carl E. Van Horn (1975), “The Policy
Implementation Process : A Conceptual Framework". Administration and Society, Vol.6, No.4.

Wahab, Solihin Abdul (2005), Analisis Kebijakan : Dari Formulasi ke Implementasi kebijakasanaan Negara. Cetakan Kelima. Jakarta : Bumi Aksara.

Werner J dan DeSmone. 2011. Human Resources Development 5th Edition. South Western Cengage Learning Mason.

Widodo, Joko (2008). Analisis Kebijakan Publik : Kosep dan Aplikasi, Analisis Proses Kebijakan Publik. Malang : Bayumedia Publishing.

Winarno, Budi (2002). Teori dan Proses Kebijakan Publik. Yogyakarta : Media Pressindo.

Yuyun Widayanti (2014). Pengembangan Karier Pustakawan Melalui Jabatan Fungsional. Jurnal Perpustakaan Libraria. Volume 2 Nomor 1.

\section{Dokumen Per Undang-Undangan}

Undang-Undang Republik Indonesia Nomor 5 Tahun 2014 Tentang Aparatur Sipil Negara.

Peraturan Pemerintah Nomor 26 Tahun 2016 tentang Pengangkatan PNS dalam Jabatan Fungsional melalui Penyesuaian/Inpassing. 
Peraturan Pemerintah Nomor 11 Tahun 2017 tentang Manajemen Pegawai Negeri Sipil.

Peraturan Menteri Kesehatan RI Nomor 64 Tahun 2015 tentang Organisasi dan Tata Kerja Kementerian Kesehatan Peraturan Menteri PANRB Nomor 25 Tahun 2016 tentang Nomenklatur Jabatan Pelaksana Bagi Pegawai Negeri Sipil (PNS) di Lingkungan Instansi Pemerintah.

Peraturan Kepala BKN No. 11 Tahun 2012 tentang Petunjuk Teknis Jabatan Fungsional Analis Kepegawaian.

Peraturan Kepala Badan Kepegawaian Negara Nomor 67 Tahun 2006 tentang Petunjuk Pelaksanaan Jabatan Fungsional Analis Kepegawaian dan Angka Kreditnya, sebagaimana telah diubah dengan Peraturan Kepala Badan Kepegawaian Negara Nomor 33 Tahun 2007.

Peraturan Kepala Badan Kepegawaian Negara Nomor 2 Tahun 2009 tentang Pedoman Penulisan Karya Tulis/Karya Ilmiah Analis Kepegawaian.

Peraturan Kepala Badan Kepegawaian Negara Nomor 3 Tahun 2009 tentang pedoman penyusunan formasi jabatan Analis Kepegawaian.
Keputusan Menteri Negara Pendayagunaan Aparatur Negara, Nomor PER/36/M.PAN/11/2006 tentang Jabatan Fungsional Analis Kepegawaian dan Angka Kreditnya sebagaimana telah diubah dengan Nomor PER/14/M.PAN/6/2008. 